\title{
WOULD THE PER SE ILLEGAL TREATMENT OF REVERSE PAYMENT SETTLEMENTS INHIBIT GENERIC DRUG INVESTMENT?
}

\author{
Bret M. Dickey* $\mathcal{E}$ Daniel L. Rubinfeld ${ }^{\dagger}$
}

\begin{abstract}
"Reverse payment" patent settlements between brand and generic pharmaceutical manufacturers have received substantial scrutiny in recent years. While much has been written about the appropriate antitrust policy towards these settlements, the literature has paid little attention to the effect that changes in that policy might have on the incentives of generic manufacturers to develop generic drugs and challenge branded patents. We present a basic economic model of generic manufacturers' investment decisions and argue that these incentives should be taken into account in evaluating policy issues. We conclude that a per se rule against "reverse payment" patent settlements could chill the incentives for generic investment by increasing the cost and uncertainty of patent litigation, and could deprive consumers of benefits from lower cost generic drugs.
\end{abstract}

fEL: L41; L65

\section{INTRODUCTION}

Patents reward innovation and stimulate research and development (R\&D). This relationship is particularly important in the pharmaceutical industry. ${ }^{1}$ $\mathrm{R} \& \mathrm{D}$ by brand-name pharmaceutical manufacturers leads to new drugs that can generate substantial benefits for consumers (as well as for the manufacturers themselves). Moreover, the entry of lower-priced generic drugs creates price competition that can also generate substantial benefits. Competition policy in the pharmaceutical industry attempts to balance the benefits of innovation by brand-name manufacturers with lower prices from generic manufacturers. The 1984 Hatch-Waxman Amendments to the Federal Food,

\footnotetext{
* Senior Vice President, Compass Lexecon. Email: bdickey@compasslexecon.com.

† Robert L. Bridges Professor of Law and Professor of Economics Emeritus, University of California, Berkeley; Professor of Law, New York University. Email: drubinfeld@law.berkeley. edu. The authors wish to thank participants at conferences at the University of Michigan Law School and the Haifa University Law School for helpful comments.

I See, e.g., Frederick M. Scherer, Pharmaceutical Innovation, in HANDBOOK OF THE ECONOMICS of TeChNological InNovation (Bronwyn Hall \& Nathan Rosenberg eds., North Holland 2010).
} 
Drug, and Cosmetic Act ("Hatch-Waxman") facilitated generic entry by easing U.S. Food and Drug Administration (FDA) approval requirements and by rewarding the first generics to file with a 180 -day period of exclusive marketing rights after generic entry. ${ }^{2}$ Those same Amendments required generic firms to notify branded manufacturers after filing an Abbreviated New Drug Application (ANDA), and led to increased patent litigation. ${ }^{3}$ While Hatch-Waxman was designed to encourage generics to challenge "weak" patents, some have raised concerns that such incentives have been substantially affected by the increased frequency of so-called "reverse payment" settlements that have the potential to delay generic entry. ${ }^{4}$

In this article, we analyze the incentives of generic firms to develop generic drugs and challenge branded patents. ${ }^{5}$ Challenges of weak patents by generic drug manufacturers are public goods. Such challenges, which can lead to generic entry well before the expiration of the patent, not only benefit the generic manufacturers, but, as a result of the ensuing price competition, leads to substantial benefits for those ultimately paying for drugs (private insurers, public insurers, and consumers). Thus, it is important to provide strong incentives for these challenges to occur. The 180-days of exclusivity that Hatch-Waxman provides first filers create an important incentive. Yet if the path to that exclusivity is too uncertain, then the 180-day exclusivity alone may not be sufficient to incentivize the optimal level of generic challenges.

Our emphasis is on the current state of antitrust policy, and more specifically antitrust policy towards patent settlements between brand and generic firms that allegedly involve compensation from brand manufacturers to generics (so called "reverse payment" settlements). The existing literature has paid little attention to the effects of antitrust policy towards patent settlements on the incentives of generic companies to develop drugs and challenge patents. ${ }^{6}$ In this article we discuss the economics underlying the generic investment decision. The analysis provides support for the

2 During the period of exclusivity, the FDA will not approve the Abbreviated New Drug Applications (ANDAs) for any other generic manufacturers of that drug. This exclusivity does not prevent entry by an authorized generic since that entry is covered by the original brand manufacturer's NDA (New Drug Application).

3 The notification occurs through a Paragraph IV Certification. The notification states that the generic believes that the patent is invalid, and/or not infringed. Once there is a Paragraph IV notification, litigation is the usual result. A suit filed by the brand manufacturer triggers a 30-month stay of the FDA's approval of the generic.

4 See, e.g., Sandoz, Inc. v. FDA, 439 F. Supp. 2d 26, 29, 33-34 (D.D.C. 2006). On the strategic behavior of patent settlements from the perspective of the generics, see Daniel F. Coughlin \& Rochelle A. Dede, Hatch-Waxman Game-Playing from a Generic Manufacturer Perspective, 25 BIOTECH L. REP. 525 (2006).

5 In what follows we use the word "challenge" to encompass both challenging the validity of patents as well as inventing around patents.

6 For an example of one opinion which does consider such incentives, see Judge Posner's Opinion in Asahi Glass Co., Ltd. v. Pentech Pharm., Inc., 289 F. Supp. 2d 986, 994 (2003). 
conclusion that a rule-of-reason analysis is appropriate in evaluating reverse payment settlements, even though those settlements can, in some cases, delay generic entry. ${ }^{7}$ Part II provides further background on "reverse payment" settlements and the focus of the Federal Trade Commission on such settlements. Part III contains our analysis of the implications of a per se rule that would disallow "reverse payment" settlements. Part IV concludes.

\section{II. "REVERSE PAYMENT" PATENT SETTLEMENTS}

"Reverse payment" patent settlements are settlements of patent litigation in which a brand manufacturer (that is, the patent holder) provides compensation of some type to a generic manufacturer (that is, the alleged patent infringer). The Federal Trade Commission (FTC) has been active in investigating these settlements, which have occurred with some frequency in recent years. ${ }^{8}$ The FTC's primary concern has been the increased cost to consumers that may result from delayed entry of generic drugs. The FTC's investigations have spanned a broad range of types of compensation, including cash, related business arrangements where compensation was not at fair market value, and agreements by brand-name manufacturers not to introduce authorized generic drugs during generic manufacturers' 180-day exclusivity periods. ${ }^{9}$

While the FTC's efforts have been less than successful to this point, the FTC's investigations continue, as does the effort of some in Congress to seek remedial legislation (either outlawing all "reverse payment" settlements or making such settlements presumptively anticompetitive, but allowing the settling parties to demonstrate that the settlements were in fact procompetitive). ${ }^{10}$

There is a substantial extant literature that analyzes many of the legal and economic issues surrounding reverse payment patent settlements. ${ }^{11}$

7 We do not discuss burden-shifting issues in this article (for example, whether it would be appropriate to presume illegality and to put the burden of proving that the settlement is pro-competitive on the settling parties).

8 See Pay-for-Delay: How Drug Company Pay-Offs Cost Consumers Billions, FTC Staff Study (2010). Neither the term "reverse payment" nor the phrase "pay-for-delay" accurately characterize the nature of all settlements. In all cases, the payments are arguably not reverse payments at all, and there may not be delay relative to a world in which there is no settlement.

9 Pay-for-Delay: How Drug Company Pay-Offs Cost Consumer Billions, FTC Staff Study (2010); Fed. TRade Comm'n, Authorized Generic Drugs: Short-Term EFFects and LONG-TERM IMPACT (Aug. 2011).

${ }^{10}$ Preserve Access to Affordable Generics Act, S. 27, 112th Cong. $\$ 17$ (2011); Protecting Consumer Access to Generic Drugs Act of 2009, H.R. 1706, 111 th Cong. (2009). For a discussion of the policy issues inherent in the regulatory maze surrounding the Hatch-Waxman Act, see C. Scott Hemphill, Paying for Delay: Pharmaceutical Patent Settlement as a Regulatory Design Problem, 81 N.Y.U. L. REv. 101 (2006).

11 See, e.g., Robert D. Willig \& John P. Bigelow, Antitrust Policy Towards Agreements That Settle Patent Litigation, 49 ANTTrRUST BULL. 655 (2004); Marc G. Schildkraut, Patent-Splitting Settlements and the Reverse Payment Fallacy, 71 ANTTTRUST L.J. (2004); Daniel Crane, Exit 
Moreover, the courts have been active as well, with different circuits (and the Federal Circuit) taking differing positions. ${ }^{12}$ Those that wish to make reverse payment settlements per se illegal emphasize the opportunity cost of delayed generic entry, the difficulty of evaluating the strength of pharmaceutical patents, and the potential availability of alternate settlements that specify a future generic entry date but do not provide for any compensation to the generic manufacturer. Those that support per se legality (at least so long as the settlement does not restrict entry beyond the scope of the patent) stress the importance of rewarding innovation by brand-name companies, and encouraging generic companies to take the risks associated with challenging branded patents, and the importance of settlements in reducing litigation costs. ${ }^{13}$

\section{ANALYSIS}

We believe that the difficult process of evaluating patent strength is essential to determining the competitive benefit of any particular patent settlement. However, the existing literature is incomplete in failing to emphasize the important relationship between competition policy towards patent settlements and generic manufacturers' incentives to develop new generic drugs. While there is obviously a difference between brand-name manufacturer $R \& D$ and the investment of generic firms, we find it instructive to characterize the development of a pipeline of generic drugs and challenges to branded patents as "generic investment."

To summarize briefly, significant benefits flow from having a substantial pipeline of generic drugs. Settlements that make generic manufacturers better off will increase the incentives to invest in new generic drugs and to challenge branded patents. Discouraging patent settlements can lead to underinvestment in patent challenges. Moreover, the "pipeline effect" could be substantially greater than the incremental benefit of earlier entry of

Payments in Settlement of Patent Infringement Lawsuits: Antitrust Rules and Economic Implications, 54 FLA. L. REv. 747 (2002); Bret Dickey, Jonathan Orszag \& Laura Tyson, An Economic Assessment of Patent Settlements in the Pharmaceutical Industry, 19 ANNALS HEALTH L. 367 (2010); James Langenfeld \& Wenching Li, Intellectual Property and Agreements to Settle Patent Disputes: The Case of Partial Settlement Agreement with Payments from Branded to Generic Drug Manufacturers, 70 ANTTTRUST L.J. 777 (2003).

12 Currently, both the U.S. Court of Appeals for the Second Circuit (see Arkansas Carpenters Health \& Welfare Fund v. Bayer AG, 604 F.3d 98, 110 (2d Cir. 2010) (per curiam)) and the Federal Circuit (see In re Ciprofloxacin Hydrochloride Antitrust Litig., 544 F.3d 1323, 1341 (Fed. Cir. 2008)) have in effect supported per se legality of patent settlements. In Valley Drug Co. v. Geneva Pharmaceuticals, Inc., 344 F.3d 1294 (11th Cir. 2003), the Eleventh Circuit took a similar position, giving substantial deference to the patent holder and to patent settlements. In contrast, the Sixth Circuit found that at least some patent settlements were per se illegal. See In re Cardizem CD Antitrust Litig., 332 F.3d 896, 908 (6th Cir. 2003).

13 See, e.g., Schering-Plough Corp. v. FTC, 402 F.3d 1056, 1060 (11 th Cir. 2005). 
individual drugs. Even if the effect on any particular development decision is modest, the cumulative effect measured over all generic development decisions can be significant. We note that a substantial fraction of litigated cases between branded and generic manufacturers are not settled. According to the 2002 FTC study, at least 60 percent of Paragraph IV litigation involving first filers was not settled. ${ }^{14}$ And, according to a more recent 2010 study by RBC Capital Markets, 53 percent of patent cases were not settled (and 46 percent were decided on the merits). ${ }^{15}$

Any reduction in the incentives of generic manufacturers to develop drugs and to challenge weak branded patents undercuts one of the key goals of Hatch-Waxman. As Hatch-Waxman recognizes, from an economic perspective, Paragraph IV challenges to weak patents benefit end payers generally, not just the generic that pursues the challenge. ${ }^{16}$ To address this problem, Hatch-Waxman granted the first-filing generic manufacturer a 180-day exclusive marketing period, during which other generic manufacturers may not compete. The 180 -day exclusivity period creates a strong incentive to challenge weak branded patents. ${ }^{17}$

\section{A. The Analytical Framework}

Patent challenges by all generic manufacturers generate public benefits, not just challenges by first filers. However, once the FDA identifies first filers, the incentive provided by Hatch-Waxman exclusivity disappears for the other generic manufacturers. Moreover, there is a real possibility that patent settlements can involve arrangements that will delay the implementation of the 180-day exclusivity period and add further delays to the entrance of additional generics. ${ }^{18}$ Nevertheless, if antitrust policy towards patent settlements reduces the ability of generic manufacturers to settle litigation and therefore increases the cost and risk associated with bringing a generic version to market, generic manufacturers' investments in these challenges are likely to

14 Of 75 lawsuits (including some that are still active) against the first filer, 20 (27 percent) settled. Of the subset of 53 lawsuits that had been resolved, 20 (38 percent) settled. See FED. Trade Comm'n, Generic Drug Entry Prior to Patent Expiration: An FTC Study 15 (July 2002).

15 RBC Capital Markets, Pharmaceuticals: Analyzing Litigation Success Rates 4 (Jan. 15, 2010). This appears to include litigation both against first filers and subsequent filers.

${ }^{16}$ See, e.g., Mark A. Lemley \& Carl Shapiro, Probabilistic Patents, 19 J. ECON. PERsp. 75 (2005).

17 According to Daniel F. Coughlin \& Rochelle A. Dede, Hatch-Waxman Game-Playing from a Generic Manufacturer Perspective, 25 BIOTECH L. Rep. 525 (2006); MARTIN A. VOET, THE Generic Challenge: Understanding Patents, FDA and Pharmaceutical LifE-CyCle MANAGEMENT (3d ed., Brown Walker 2011), more than half of all generic profits are earned during the 180-day exclusivity period.

18 C. Scott Hemphill \& Mark A. Lemley, Earning Exclusivity: Generic Drug Incentives and the Hatch-Waxman Act, ANTITRUST L.J. 947 (2011). 
be diminished. That would reduce the number of generic drugs in the future "pipeline." In the long run, a reduction in the number of generic entrants would likely lead to higher average pharmaceutical prices.

Antitrust policy towards patent settlements can lead to over-deterrence if the negative effect on the "pipeline" of generic manufacturers that file ANDAs and make Paragraph IV certifications outweighs the benefits generated by earlier entry for particular drugs. Even if antitrust policy has only a modest effect on individual generic manufacturers' incentives to develop new drugs, the cumulative effect across all development decisions by all generics can be substantial. Despite the cost of preparing and filing an ANDA, ${ }^{19}$ the number of Paragraph IV ANDAs filed is large and increasing-having grown from almost 100 in 2000 to almost 300 in $2007 .^{20}$ Moreover, a substantial fraction of Paragraph IV filings lead to generic entry prior to patent expiration. ${ }^{21}$ It follows that an antitrust policy that did not distinguish anticompetitive from procompetitive settlements, and that consequently reduced the number of ANDAs filed, could result in less, rather than more, generic competition and higher, rather than lower, drug prices. Determining the extent of this adverse impact on generic competition is a difficult exercise about which much remains unknown.

\section{B. The Policy Alternatives}

In the analysis that follows, we begin by sketching out the factors that should be taken into account in a rule of reason analysis. We show that the welfare effects of antitrust intervention against a patent settlement are a function (among other things) of the strength of the underlying patent at issue and the magnitude of the costs of the patent litigation. If the patent is strong and the settlement involves entry substantially earlier than the date of patent expiration, then it is quite possible that the settlement will (in

19 An ANDA costs approximately $\$ 1$ million to prepare. Id. (citing Requirements for Submission of In Vivo Bioequivalence Data; Proposed Rule, 68 Fed. Reg. 61,640, 641, 645 (Oct. 29, 2003)).

20 FTC, AUTHORIzed Generic DRUGS, supra note 9. The total number of ANDAs filed in 2007, including Paragraph I, II, and III certifications, was nearly 900 . For data on the number of generic filing ANDAs, see GeNERIC Pharmaceutical Association, Generics: The RIGHT ChOICE FOR BETTER HEALTH 25 (2008). A large fraction of ANDAs are ultimately approved. In 2007, the FDA granted final approval to nearly 500 ANDAs.

21 According to the 2002 FTC study, branded manufacturers win only about 10 percent of Paragraph IV challenges and about another 30 percent are settled. In the other roughly 60 percent of cases, the branded manufacturer does not sue, the generic manufacturer wins the suit, or the generic manufacturer is otherwise able to enter. FED. TRADE COMM'N, GENERIC DRUg ENTRY Prior to PATENT Expiration: AN FTC StUdy 14-15 (July 2002). Notably, this study largely covered a period where patent settlements received little antitrust scrutiny. As mentioned, a 2010 RBC study suggests that 76 percent of Paragraph IV challenges lead to generic entry prior to patent expiration (through the generic winning the lawsuit, the brand-name manufacturer dropping the lawsuit, or a settlement). 
expectation) reduce, rather than increase drug prices. We show, by illustration, that it is quite possible for a "reverse payment" patent settlement to be in the interests of the parties and at the same time be in the public interest.

Consider a patent suit in which the brand is likely to be successful (through trial and appeals) with a probability of 50 percent. If there were no settlement and the patent is determined to be invalid or not infringed, then the first ANDA-filing generic will typically enter when the litigation is complete. ${ }^{22}$ If a court determines that the patent is valid and infringed, then there will be no generic entry until after patent expiration. A patent settlement, therefore, leads to earlier generic entry than would occur if the patent were valid and infringed, but to delayed generic entry when the patent is not valid or not infringed. (If there had been no Paragraph IV challenge, generic entry would most likely occur immediately after the brand patent expired.) Patent settlements that delay entry by a generic version of the drug at issue, are, other things the same, likely to reduce consumer welfare.

Reverse payment patent settlements, however, do not necessarily delay generic entry. Even those settlements that do result in delays in generic entry relative to the expected outcome from litigation, could increase welfare to the extent they avoid the substantial costs or uncertainty associated with litigation, and/or provide increased incentives for generics to invest in pursuing future challenges.

The perspective of the FTC appears to be that for every "reverse payment" settlement there exists a settlement without a payment and an earlier entry date that will increase social welfare. Whether such an outcome is indeed feasible is not at all clear. The economics literature demonstrates that under some real-world circumstances (for example, in the presence of risk aversion, asymmetric information, asymmetric beliefs, or liquidity constraints), a "reverse payment" can be essential to facilitating a procompetitive settlement between the parties. ${ }^{23}$ For example, suppose that the generic manufacturer was having difficulty raising needed capital from the financial markets. ${ }^{24}$ As a result, the generic manufacturer would substantially discount future profits and only be willing to settle the litigation if it allowed relatively early entry. But the patent may be strong enough that the brandname manufacturer would not be willing to agree to such an early entry date. Compensation from the brand-name manufacturer may allow the parties to bridge the settlement gap to find an entry date that is acceptable to both parties and earlier-than-expected entry, should the parties continue to litigate.

22 In recent years, a number of generics have entered prior to the completion of the appeals process, most often after having had success at the district court level.

23 See, e.g., Carl Shapiro, Antitrust Limits to Patent Settlements, 34 J. RAND Econ. 391 (2003); Willig \& Bigelow, supra note 11.

24 See Dickey, Orszag \& Tyson, supra note 11, at 392-94, for a more complete description of this example. 
We conclude that it is important to account for generic investment incentives when evaluating current enforcement actions and when considering reforms of the Hatch-Waxman Act.

\section{Investment Incentives}

It is clear that the brand manufacturer faces substantial risk when a generic firm files a Paragraph IV certification. On the upside, the manufacturer could win the patent suit. ${ }^{25}$ On the downside, the manufacturer could lose the patent suit and most of its profits from that brand-name drug. A settlement makes the brand manufacturer better off (or the brand manufacturer would not have agreed to such a settlement) and as a result increases the incentive to invest in $R \& D$ relative to a world in which such settlements are outlawed. Absent a settlement, $R \& D$ incentives will be greater the more likely it is that any claimed patent will be valid. However, for a given patent, settlement will benefit the brand manufacturer the most (and be most likely to harm consumers) when the patent is relatively weak.

Generic manufacturers also face risks. The decision to file a Paragraph IV certification is highly risky, with the downside greater the stronger the patent. ${ }^{26}$ The risk is reduced when a patent settlement is reached which allows the generic to enter the market at a certain date. From the generic's perspective, the settlement benefits are greater the stronger the patent, other things the same. If the generic does opt to settle rather than litigate, it is clearly better off (otherwise it would not have chosen to settle). Furthermore, the generic's incentive, and the incentive of other generics to invest in developing new generic drugs and in entering and challenging brand patents, increases.

A generic manufacturers' decision to challenge a branded patent and develop a new drug has the same general characteristics of any investment decision. ${ }^{27}$ The manufacturer compares the expected net present value of future cash flows generated by the investment, discounted to appropriately account for the risk associated with that investment, to the expected cost of the investment.

The costs of bringing a new generic drug to market include the ANDA filing costs, the $R \& D$ costs of demonstrating to the FDA that the generic

25 However, the upside value may be limited to the extent that the generic is unable to fully compensate the brand manufacturer for the infringement losses if the generic enters prior to the resolution of the patent suit.

26 The risk is even greater if the generic enters at risk, that is, before the patent litigation has been fully resolved.

27 For a more detailed discussion of the generic entry decision, see Fiona $M$. Scott Morton, Entry Decisions in the Generic Pharmaceutical Industry, 30 RAND J. EcoN. 421 (1999). For an empirical analysis of the factors that affect a generic manufacturer's decision to file a Paragraph IV challenge, see C. Scott Hemphill \& Bhaven N. Sampat, When Do Generics Challenge Drug Patents?, 8 J. EMPIRICAL LEgal STUD. 613 (2011). 
manufacturers' version is bioequivalent to the branded drugs, ${ }^{28}$ and, importantly, the costs of patent litigation with the branded manufacturer. ${ }^{29}$ All else equal, these costs will be higher for drugs that are difficult to manufacturer, and for drugs that are supported by "strong" patents (that is, patents that are likely to be found valid and that are difficult to invent around).

The related revenues include the net present value of future profits from successfully marketing the generic drugs. All else equal, these revenues will be higher when: (1) the current sales volume of the branded drug is large; (2) the sales volume of the branded drug will be stable or grow; (3) there will be fewer generic competitors; and (4) the generic manufacturer earns 180 days of marketing exclusivity from the FDA.

Of course, this investment decision is risky, since there is substantial uncertainty associated with many of the components just described. Moreover, the prospect for, and timing of, FDA approval is difficult to predict. In addition, the "entry" decisions (that is, the ANDA filings) of other generic competitors are not known. As a result, there is often substantial uncertainty over whether a generic manufacturer will be in line to receive the 180-day period of exclusivity and how many competing generics will also enter.

The outcome of the patent litigation is highly unpredictable as well. While the branded drug may have substantial sales at the time of filing, a new therapeutic competitor or a follow-on product by the brand manufacturer may significantly limit the future sales for which the generic can compete. The ANDA and litigation processes can take years, and the competitive environment can change dramatically from the time of the initial entry decision. Having the option to settle the patent litigation helps to mitigate at least one aspect of this uncertainty.

We highlight the uncertainty of generic investment with an example. Assume hypothetically that a small generic manufacturer begins development of a generic version of a low-volume branded drug with no patent listed in the Orange Book. Assume also that in the early stages of the process the branded manufacturer lists a new patent in the Orange Book. That listing implies that the generic manufacturer's development is now potentially infringing. Finally, assume that there is a second generic manufacturer that files an ANDA shortly before the first. What originally started with a small manufacturer developing a generic version of a low-volume branded drug without any patent protection, could turn into a protracted and expensive patent litigation where the generic manufacturer did not even

${ }^{28}$ FTC, AUThORIzed GeNERIC DRUGS, supra note 9, estimated, based on generic manufacturers' responses to Special Order specifications, mean expenditures associated with filing an ANDA of approximately $\$ 1$ million (with an inter-quartile range of approximately $\$ 900,000$ to $\$ 1.2$ million).

29 The FTC estimated, based on generic manufacturers' responses to Special Order specifications, mean expenditures on Paragraph IV litigation of approximately $\$ 5$ million (with an inter-quartile range of approximately $\$ 2$ million to $\$ 6$ million). $I d$. 
have the potential reward of exclusivity. In a world in which "reverse payment" settlements are per se illegal, the generic manufacturer may not have been able to settle this litigation. Without the ability to settle, such substantial uncertainties can dramatically chill the incentives of a generic manufacturer to develop generic drugs.

Ensuring that generic manufacturers have a viable option to settle patent litigation reduces the uncertainty associated with investing in a new generic drug and, all else equal, increases generic manufacturers' incentives to invest in new drugs. Increased competition from generic manufacturers leads to lower drug prices. Thus, to the extent that (procompetitive) reverse payment settlements are important to preserving this option, a policy that treats reverse payment settlements under a rule of reason approach can lead to increased generic competition, lower prices, and increased consumer benefits, relative to a policy that bans all reverse payment settlements.

\section{CONCLUSION}

We have stressed the importance of generic investment in any evaluation of the pros and cons of competition policy toward patent settlements that involve reverse payments. Generic investment is another factor that we believe suggests that the appropriate policy towards such settlements should be rule of reason rather than per se.

Incentives for generic investment are also important when evaluating proposed changes to Hatch-Waxman itself. Scott Hemphill and Mark Lemley have recently proposed an amendment that would restrict the award of 180-day exclusivity to one of three scenarios: (1) the generic successfully defeated the patent owner by invalidating the patent or proving that the patent was not infringed; (2) the generic filed a Paragraph IV certification but the patent owner did not sue for infringement; or (3) a generic settlement was reached that "permits entry without delay." Under this proposal, if a generic manufacturer settles the litigation with an agreed entry date in the future, whether or not that date includes a "reverse payment," the generic would forfeit any exclusivity period. The authors argue that limiting the use of the 180-day exclusivity incentive and some of the strategic manipulations of that rule would be beneficial. Among other things, they point to the relatively modest price reductions that occur when the first generic enters and the much more substantial price reductions that occur when there are two or more generics in the market.

Amending the Hatch-Waxman Act is another way to affect the policy balance in the pharmaceutical industry that should be given consideration. For one thing, the current circuit splits generate mixed messages and uncertain incentives for both generic and brand manufacturers. For another thing, the evaluation of the competitive implications of ever-more complex patent settlements is likely to be costly and itself highly uncertain. Nevertheless, we 
do not see the Lemley-Hemphill proposal as the ideal solution. Outlawing settlements without reverse payments unless exclusivity is relinquished would substantially decrease the expected benefits of settlement. We are concerned that the Hemphill-Lemley proposal will reduce the incentive of generics to invest in new potential drugs and that the resulting reduction in the generic pipeline will lead to higher pharmaceutical prices in the long run. ${ }^{30}$ Like Hemphill and Lemley we see the magnitude of generic investment incentives as an important, and to this date unanswered, empirical question.

${ }^{30}$ C. Scott Hemphill \& Bhaven N. Sampat, When do Generics Challenge Drug Patents?, 8 J. EMPIRICAL LEGAL STUD. 613 (2011) find that the size of the market is an important predictor of the number of generic entrants. However, their study does not offer evidence as to how the number of generics would change if the incentives to enter were altered either by the Courts or by Congress. 
